those termed English include several varieties of foreign origin which are commonly grown in England. In most cases the trees were on the crabstock :-

\begin{tabular}{|c|c|c|c|c|c|}
\hline II7 English & $\cdots$ & $\cdots$ & & & May 6.4 \\
\hline 36 Scotch & $\ldots$ & $\ldots$ & $\ldots$ & $\ldots$ & May 8.9 \\
\hline 9 Irish & $\ldots$ & $\ldots$ & $\ldots$ & ... & May 9.4 \\
\hline 8 French & $\ldots$ & $\ldots$ & $\ldots$ & $\ldots$ & May $9 \cdot 0$ \\
\hline (i German & $\ldots$ & $\ldots$ & $\ldots$ & $\ldots$ & May $4 \cdot 0$ ) \\
\hline 7 Russian & $\ldots$ & $\ldots$ & $\ldots$ & $\ldots$ & May 8.6 \\
\hline
\end{tabular}

Another point of some interest in connection with these results may be mentioned, namely, that there is a connection between the earliness of blossoming and the earliness of the ripening of the fruit, though it is so slight that it becomes apparent only when the averages of a considerable number of varieties are taken, and many individual instances may be noticed where the later fruit follows the earlier blossoming :-

$$
\begin{array}{lllll}
37 & \text { Early varieties } \ldots & \ldots & \ldots & \text { May } 4 \cdot 7 \\
\text { 40 } \text { Mid-season varieties } & \ldots & \ldots & \text { May } 6 \cdot 3 \\
\text { 40 Late varieties } \ldots & \ldots & \ldots & \text { May } 8 \cdot 0
\end{array}
$$

This letter, I fear, is already too long, but it leaves unmentioned several points which may be of importance in determining the fruiting of trees.

Spencer Pickering.

\section{Artificial Diamonds.}

Of the two phases, diamond and graphite, diamond is the denser, and has also the less internal energy. It follows that, if carbon can be crystallised at comparatively low temperatures, the minimum pressure sufficing to determine the diamond form will be lower than that employed in M. Moissan's experiments.

For estimating the transformation temperature corresponding to low pressures, the data available are incomplete; it is here suggested, however, as a tentative result from experiments which are still in a preliminary stage, that the transformation temperature corresponding to atmospheric pressure lies somewhere between $550^{\circ} \mathrm{C}$. and $700^{\circ}$ C., or not far outside those limits, temperatures having so far been judged only by eye.

A molten alloy of lead with about I per cent. calcium appears to be capable of holding in solution some small proportion of carbon, which exists either as free carbon

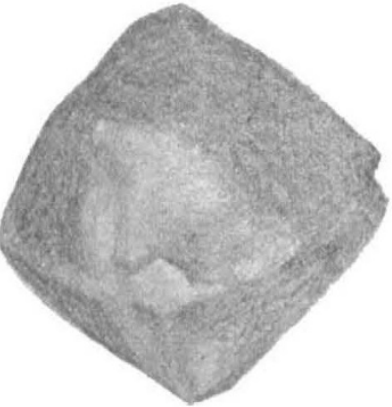

FiG. 1.-Supposed diamond from leadcalcium-carbon solution. or as calcium carbide; and if the calcium is eliminated from the molten mass, some carbon crystallises out. Steam, for example, converts the calcium into hydrate without attacking the lead. If the reaction has occurred at a full red heat, graphite is found in the crust of lime; if only a very low red. heat has bren attained, no graphite is found, but a number of very small or microscopic crystals, which have many of the properties of the diamond. The illustration is from a pencil drawing of a very minute crystal, viewed under a magnification of 80 diameters, and drawn on a greatly enlarged scale.

The crystals obtained exhibit mostly faces of the octahedron, modified by the cube and dodecahedron; in no case has any internal flaw or lack of perfect transparency been detected in them. The refractive index is clearly very high, and an attempt to determine it by displacement of focus gave 2.43 (instead of 2.47 ), any convexity of the refracting surface tending to give too low a value. The crystalline faces are, in fact, generally if not always convex, in many cases strongly so. The crystals adhere tenaciously to clean, dry glass; they are unacted upon by ordinary acids (hot or cold), by cold hydrofluoric acid, and by fused alkali at a red heat. When strongly heated on No. I869, voL. 72$]$ platinum foil, they burn away, leaving no residue. The quantities at present available are too small for the ready determination of density or hardness.

Negative results were invariably obtained in control experiments on the commercial calcium carbide which was used in preparing the alloys.

Tin may be used in place of lead, but it is freely oxidised by the steam, and the resulting dioxide is troublesome to get rid of. Of other reactions which appear to have yielded minute crystals of diamond, the following may be mentioned:-boiling benzene or toluene in contact with finely powdered potassium dichromate or with concentrated aqueous solution of gold chloride; heating benzene or toluene mixed with carbon tetrachloride or chloroform to $200^{\circ} \mathrm{C}$. to $300^{\circ} \mathrm{C}$. in a bomb. In the last named reactions, nearly all the carbon separates out in the amorphous form, hydrochloric acid collecting under enormous pressure.

I hope shortly to return to the subject of these experiments, and to make a fitting acknowledgment of my deep indebtedness to Mr. W. J. Hartley, to Messrs. Neville and Hevcock, and to other friends.

C. V. Burton.

4 Chesterton Hall Crescent, Cambridge, August 19.

\section{The Spread of Injurious Insects.}

IN 1898 Dr. I. O. Howard forwarded to me a scale insect discovered by Prof. Chaves at Ponta Delgada, Azores, attacking the foliage of the orange tree. The insect proved to be new, and was described as Lecanium perlatum. Since that time it has never been reported from any other place; but now I have received some large, flat, dark brown scales on orange leaves from Villa Encarnacion, Paraguay, collected by Mr. Schrottky, and they are this very same L. perlatum. ${ }^{1}$ This is only one new case to be added to the many already known of scale insects being transported from one side of the world to the other, evidently by human means. It is to be regretted that the British Government, with its numerous tropical colonies and excellent botanical gardens, has not done something to make known the scale insects within its domains. It is true that Mr. E. E. Green, the Government entomologist of Ceylon, is bringing out a magnificent work on the scale insects of that island; but he finds insufficient support, and it is divulging no secret to say that the publication of this useful book will involve him in very serious financial loss. There is no properly classified national collection of scale insects (the only good collection in England is that of Mr. Newstead at Liverpool), and we are still totally ignorant of the coccid fauna of many colonies. The reasons for regretting this condition of affairs are mainly two:--(I) because in ignorance pests of this group are continually being carried to new regions, where they are liable to become destructive; and (2) because man is so mixing up the distribution of these insects that every year makes it more difficult to ascertain their natural habitats. Having regard for the experiences of the past, it is surely safe to say that the annual expenditure of a few hundred pounds in the investigation of these pests would be far more than repaid in economic as well as scientific gains.

University of Colorado, U.S.A., August 1o.

\section{A Parasite of the House-fly.}

I SHOULD like to direct attention to an interesting parasite of the house-fly which is in this district extremely abundant this summer. The creature is, as a rule, very hard to find, and many thousands of flies may be caught in ordinary seasons without a single parasite being found upon them. The animal in question is one of the PseudoScorpionides (? Chelifer), easily recognisable by its pair of long chela, and I should be glad if any of your readers would inform me to what genus it belongs and whether it is equally abundant this year in other places.

\section{Eton, August 19.}

M. D. Hill.

1 In my original description, it is stated that the skin is not reticulated. The new material shows that it is minutely reticulated or tessellate in the middle of the back. The antennæ, described as 8 -jointed, vary to 7 -jointed, with the fourth joint longest, but the third nearly as long. 